\title{
Mimotopes for Mycotoxins Diagnosis Based on Random Peptides or Recombinant Antibodies from Phage Library
}

\author{
Wei Sun ${ }^{1}$, Yan Zhang ${ }^{1}$ and Zhigang Ju ${ }^{2, *}$ \\ 1 Key Laboratory of Plant Physiology and Development Regulation, School of Life Science, \\ Guizhou Normal University, Guiyang 550001, China; sunwei889@163.com (W.S.); \\ 15186346268@163.com (Y.Z.) \\ 2 Pharmacy School, Guizhou University of Traditional Chinese Medicine, Guiyang 550025, China \\ * Correspondence: juzhigang008@gzy.edu.cn
}

Citation: Sun, W.; Zhang, Y.; Ju, Z Mimotopes for Mycotoxins Diagnosis Based on Random Peptides or Recombinant Antibodies from Phage Library. Molecules 2021, 26, 7652. https://doi.org/10.3390/ molecules26247652

Academic Editors: Alessandra Gentili and Chiara Fanali

Received: 29 October 2021

Accepted: 14 December 2021

Published: 17 December 2021

Publisher's Note: MDPI stays neutral with regard to jurisdictional claims in published maps and institutional affiliations.

Copyright: (c) 2021 by the authors. Licensee MDPI, Basel, Switzerland. This article is an open access article distributed under the terms and conditions of the Creative Commons Attribution (CC BY) license (https:// creativecommons.org/licenses/by/ $4.0 /)$.

\begin{abstract}
Mycotoxins, the small size secondary metabolites of fungi, have posed a threat to the safety of medicine, food and public health. Therefore, it is essential to create sensitive and effective determination of mycotoxins. Based on the special affinity between antibody and antigen, immunoassay has been proved to be a powerful technology for the detection of small analytes. However, the tedious preparation and instability of conventional antibodies restrict its application on easy and fast mycotoxins detection. By virtue of simplicity, ease of use, and lower cost, phage display library provides novel choices for antibodies or hapten conjugates, and lead random peptide or recombinant antibody to becoming the promising and environmental friendly immune-reagents in the next generation of immunoassays. This review briefly describes the latest developments on mycotoxins detection using M13 phage display, mainly focusing on the recent applications of phage display technology employed in mycotoxins detection, including the introduction of phage and phage display, the types of phage displayed peptide/recombinant antibody library, random peptides/recombinant antibodies-based immunoassays, as well as simultaneous determination of multiple mycotoxins.
\end{abstract}

Keywords: mycotoxins; phage display; scFv; anti-idiotypic nanobody; simultaneous determination

\section{Introduction}

Mycotoxins are nonvolatile and relatively low-molecular weight secondary metabolites produced by a variety of microscopic fungi. As mycotoxins are natural contaminants that exist in cereal, vegetables, milk and herbal medicine, they cannot be completely eliminated without damaging food. For fungi, mycotoxins are beneficial and play important roles in eliminating other microorganisms or invading host tissues. However, for animals, mycotoxins are acutely or chronically toxic, which interfere with absorption and metabolism of nutrients, resulting in the damage of endocrine and neuroendocrine functions, or suppression of the immune system [1-3]. Hence, stringent regulations relating to mycotoxins have been established to protect the consumer from their harmful effects [4].

To date, many food regulatory authorities have set maximum residue limits (MRLs) for mycotoxins, including EU, USA, China, etc. Even regulated mycotoxins and commodities, as well as MRLs, vary significantly in different countries; the request for analytical methods for mycotoxins detection is a worldwide priority. In order to meet the requirements of these regulations, many analytic methods for identification and quantification of mycotoxins have been developed, such as high performance liquid chromatography (HPLC) [5], liquid chromatography coupled with mass spectrometry (LC-MS) [6], gas chromatography coupled with mass spectrometry (GC-MS) [7,8], and so on. Although these methods provide excellent accuracy and reproducibility, there are still special limitations in actual practice, such as being relatively high cost, time-consuming, requiring of a skilled 
technical personnel, and any of these weaknesses make them unsuitable for quick and easy detection.

Alternatively, by the specific interaction of antibodies to mycotoxins hapten, immunoassays have particularly attractive properties in mycotoxins detection, for example, low cost, strong specificity, high sensitivity, fast test and simple operation [9]. Moreover, antibodies as one of the biorecognition elements, can exploit antibody-antigen interaction for specific detection of a particular analyte from complex matrices. Depending on the principles of detection, immunoassay can be mainly divided into four formats, including direct immunoassay, indirect immunoassay, sandwich immunoassay, and competitive immunoassay. Among these assays, sandwich immunoassay is mostly applied for detection of macromolecules, and competitive immunoassay is usually used for the detection of small molecules. The competitive immunoassay is frequently applied for low molecular weight mycotoxin detection, basing on the competitive binding between anti-mycotoxin antibody and mycotoxin conjugates. Until now, many portable immunoassay techniques have been developed for detection of small analytes. For instance, the lateral flow immunochromatographic assays (LFIAs), optimal suited for on-site test formats, require only the addition of the sample and can result in a readable signal [10]. The critical biochemical reagents in competitive immunoassay are the used antibody and hapten-conjugate. Nevertheless, the prepare processes of antibodies and the traditionally used hapten-protein conjugates are complicated, time-consuming, and expensive, which partly restricts their wide range of application.

On the one side, a large number of antibodies against various mycotoxins have been produced, such as monoclonal antibodies, polyclonal antibodies, and recombinant antibodies [11-13]. Nowadays, antibodies continue to be the predominant immunoreagent and some improvements of preparation have been introduced $[14,15]$. While validation of antibodies is often lacking, which may be a major limitation considering the quality and consistency of antibody-based technologies [16]. Meanwhile, the traditional antibodies need animal immunizations, longer time and larger expenses, which also influence their widespread use. On the other side, haptens cannot elicit an immuno response, so many artificial antigens conjugated with proteins were produced, like bovine serum albumin (BSA). However, mycotoxins conjugated with proteins still keep toxicity, and may produce toxic effects on the operators. Furthermore, analyte conjugation can unfavorably affect antibody recognition, or the release of the analyte moiety from the conjugate might even cause false positive results $[17,18]$. In addition, antigen-conjugates are not suitable for a large scale production with low cost. For example, the expenses of artificial antigen of fumonisin ( $\mathrm{FB}_{1}$ )-BSA, zearalenone (ZEN)-BSA and ochratoxin (OTA)-BSA were $\$ 193.344$, $\$ 20.858$ and $\$ 77.427$, respectively [19].

Peptide mimics and recombinant antibodies are interesting alternatives to overcome above limitations. Therefore, more and more researchers have shifted the emphasis to alternatives of antibodies and mycotoxin conjugates. In general, there are two ways. One conventional approach is to generate anti-idiotype antibodies (AIds), which are raised against the variable regions of the original antibody or mycotoxins. For example, some AIds against various mycotoxins have been prepared successfully by monoclonal, polyclonal, or alpaca nanoantibody technology, such as $\mathrm{FB}_{1}$, aflatoxin $\left(\mathrm{AFB}_{1}\right)$, deoxynivalenol (DON) [20-23].

Another approach to develop AId is via the phage displayed peptide technology. Phage-displayed peptide, which can mimic the antibody binding site on the antigen, has been demonstrated to be an alternative to the specific recognition for various targets. Phage-displayed peptides have been used in a number of applications, containing epitope mapping [24,25], molecular imaging [26], targeting drug delivery $[27,28]$ and defining the protein-protein interactions [29,30]. Mimotopes for mycotoxins have also been selected through using phage display technology [31-34]. The mimotopes have been utilized for the detection of mycotoxins in the form of phage themselves or synthetic peptides. Moreover, combined toxic effects of mycotoxins have co-existed in agro-products [35]. So multiplexed 
detection of target analytes are of great significance owning to the advantages of timesaving, cost-effective, and high-throughput screening. This review focuses on the recent applications of phage display technology using for toxin detection, including the introduction of phage and phage display, the types of phage displayed peptide/recombinant antibody library, random peptides/recombinant antibodies-based immunoassays and simultaneous determination of multiple mycotoxins.

\section{M13 Phage Display Technology}

\subsection{The Structure and Life-Cycle of M13 Bacteriophage}

M13 phage is one kind of rod-like filamentous phages with $1 \mu \mathrm{m}$ long and $6 \mu \mathrm{m}$ in diameters. As the demonstration in Figure 1A, a single-stranded DNA (ssDNA) was encapsuled in a protein tube, which composed mainly of systematically arranged molecules of pVIII ( 2700 copies), named major coat protein. Meanwhile, 5 copies of pIII and pVI are located at one tip of the particle, 5 copies of pVII and pIX are presented at the other tip, which respectively formed the "head" and "tail" of phage, named minor coat protein [36].

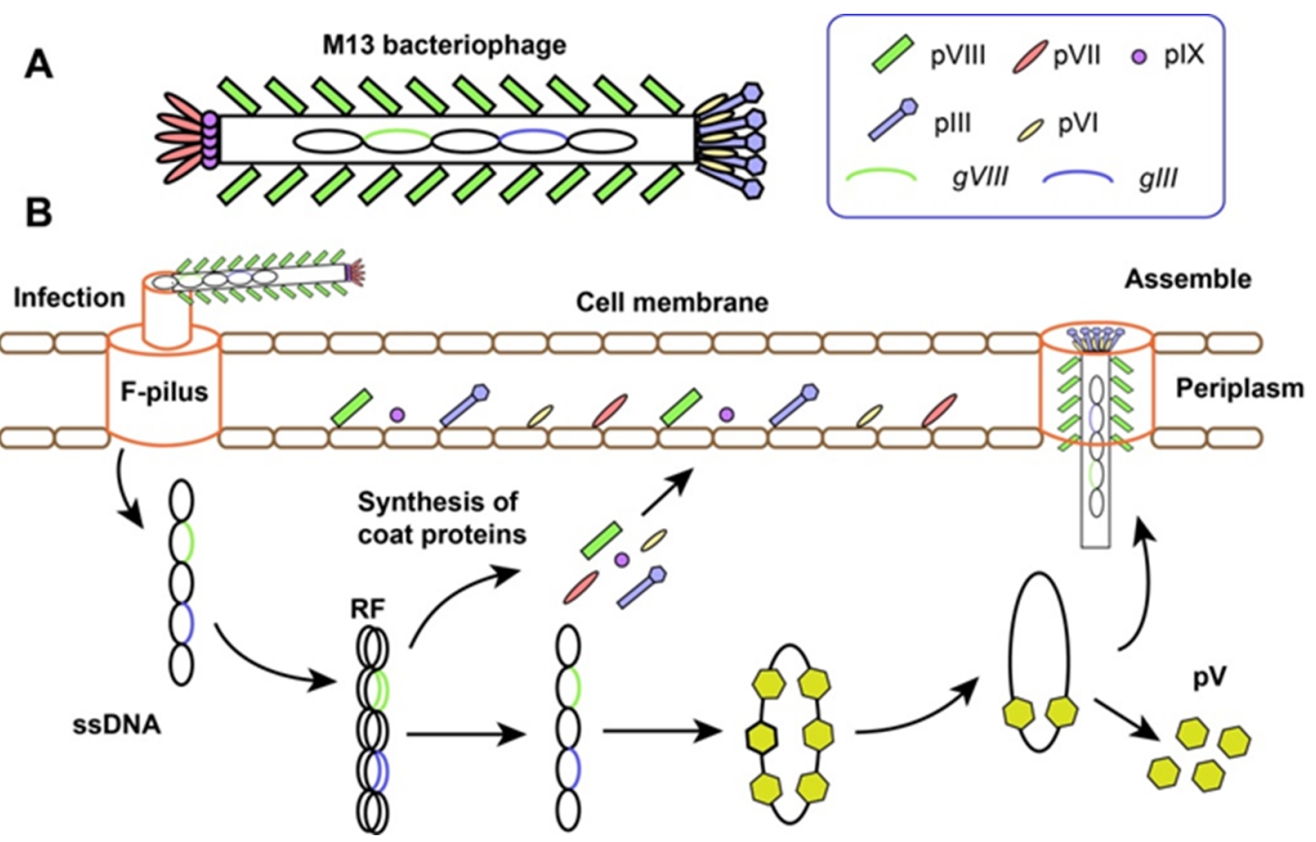

Figure 1. The basic structure (A) and life cycle (B) of filamentous bacteriophage.

Filamentous bacteriophage can produce vast progenies in a short time without killing the host, which is different from lytic and lysogenic phages (Figure 1B). Relying on the adhesion between F pilus of E. coli bacteria and N-terminal domain of pIII, the whole phage is drawn into the periplasm of the cell. Only ssDNA is injected into the cytoplasm, and leaving the coat proteins outside. Taking advantage of the host machinery, a doublestranded replicate form (RF) DNA is synthesized, which provides the template for the transcription of phage genes and duplication of progeny ssDNAs. Then, all 5 coat proteins containing signal peptides are synthesized and secreted into the periplasm, where intact progeny phages are assembled successfully. The ssDNA carrying $\mathrm{pV}$ dimers produces packaging signal, which initiates the self-assembly. The "head" is formed first, while the "tail" is synthesized at last. The length of phage and number of pVIII are all determined by the size of ssDNA [37-39]. During the process of self-assembly, coat proteins arranged ordered in a special pattern. For example, pVIII always retains its N-terminal part outward, which allows foreign peptides or proteins display on the surface of phage particles.

\subsection{Phage Display Technology}

Phage display is a technology that can display foreign proteins or peptides on the surface of phage rods, either on the backbone or on both ends, which can achieve by tar- 
geted insertion of DNA sequence encoding foreign proteins or peptides. More importantly, foreign proteins or peptides still retain their ability to recognize the molecular targeting binding site. As early as in 1985, the restriction endonuclease EcoR I was first fused to pIII as recombinant minor coat proteins by Smith [40]. Subsequently, pVIII and pVI coat proteins can also be utilized for phage display [41-43] and even double display system is innovatively proposed [44].

Vectors of M13 bacteriophage used in phage display can be classified into different types, including type $3+3$, type $6+6$ and type $8+8$ vectors. Among them, the foreign peptides encoded by the phagemid genome are named phagemid vectors. While the foreign peptides are encoded by phage genome are called phage vectors. Based on the number of displayed foreign peptides, phage vectors mainly classified into type $3 / 8$ vectors and type 33/88 vectors, in which the displayed peptides fused to all copies of coat proteins or a fraction of them. Absolutely, some novel phage display systems have also been developed based on above phage or phagemid vectors. As reported by Wang et al. [44], magnetic nanoparticle-binding peptides and anti-sap2 antibody-binding peptides were separately displayed on pVIII and pIII to form a bi-functional nano-fibers using for the detection of Candida albicans. Meanwhile, various phage libraries comprising about $10^{9}$ variants are constructed, such as random peptide phage library [45], antibody phage library [46] and cDNA phage library [47], which lay a foundation for the study of bio-panning of targeted binding peptides and enzyme evolution. Next, we will review the main types of phage display libraries reported with respect to mycotoxins detection and discuss their construction methods, applied ranges, strengths and weaknesses.

\section{Random Peptide Using for Mycotoxins Detection}

\subsection{Random Peptide Libraries}

Random peptide libraries are the most common type of phage display library. Originally, random peptide, also called mimotopes, was applied to discover antibody-binding ligands whose specificity is not known in advance [48]. By direct insertion of peptide cDNA between the signal peptide and the $\mathrm{N}$-terminus of the coat protein pIII, degenerate oligonucleotides can be introduced into the phage genome [39]. Then, random peptides were displayed on the surface of phage along with the propagating of phage particles. Furthermore, the detailed construction methods of random peptide libraries had been deeply reviewed by Kehoe and Kay [49]. According to the structure and length of peptide, a linear random peptide library varying in length from 6 to 43 amino acids and a loop random peptide library were constructed, respectively. Notwithstanding many random peptide libraries had been created for now, only few libraries were developed into a commodity for sell, such as Ph.D. ${ }^{\mathrm{TM}}-12$ Phage Display Peptide Library and Ph.D. ${ }^{\mathrm{TM}}-7$ Phage Display Peptide Library Kit.

A random peptide library may display tens of millions of peptide epitope, which makes phage display derived products play a significant role in the diagnosis and treatment of diseases. Macromolecules, bacteria, cells, tissues, organs, animals, and even nanoparticles [50-55] can all serve as the targets for bio-panning to obtain specific binding peptides. Therefore, many peptide mimotopes of mycotoxins have been identified through affinity selection from phage display libraries (Table 1), such as $\mathrm{OTA}, \mathrm{AFB}_{1}, \mathrm{FB}_{1}$ and DON et al. In order to obtain mimotopes with higher affinity, a second generation peptide library had been constructed based on the identical sequence from the initial random peptide library. He et al. screened OTA from second-generation peptide library, which could improve the sensitivity approximately 10-fold [56]. 
Table 1. Mycotoxins-binding mimotopes screened from phage display library.

\begin{tabular}{|c|c|c|c|c|c|c|c|c|}
\hline Mycotoxin & Library & $\begin{array}{l}\text { Passenger } \\
\text { Protein }\end{array}$ & Peptide Mimics & Linear Range & LOD & $\begin{array}{l}\text { Detection } \\
\text { Principle }\end{array}$ & $\begin{array}{l}\text { Sample } \\
\text { Matrices }\end{array}$ & Ref. \\
\hline DON & $\begin{array}{l}\text { Random 7-mer } \\
\text { peptide library }\end{array}$ & $\mathrm{pIII}$ & $\begin{array}{l}\text { SWGPFPF; } \\
\text { SWGPLPF }\end{array}$ & $0.1-10 \mu \mathrm{g} / \mathrm{mL}$ & - & Competitive ELISA & Wheat & [31] \\
\hline \multirow{3}{*}{$\mathrm{AFB}_{1}$} & $\begin{array}{l}\text { Random 8-mer } \\
\text { peptide library }\end{array}$ & pIII & $\begin{array}{l}\text {-PHPWNP-; } \\
\text {-T-HRNW- }\end{array}$ & $4-24 \mu \mathrm{g} / \mathrm{kg}$ & - & Competitive ELISA & Peanut and feedstuff & [33] \\
\hline & $\begin{array}{l}\text { Random Cys-4/Cys-6 peptide } \\
\text { library }\end{array}$ & pVIII & CYMD-C & - & - & Competitive ELISA & Groundnut & [57] \\
\hline & $\begin{array}{l}\text { Ph.D. TM_7 Phage } \\
\text { Display Peptide Library }\end{array}$ & pIII & HPSDPRH & $100-2500 \mathrm{pg} / \mathrm{mL}$ & - & Competitive ELISA & $\begin{array}{l}\text { Rice, wheat, corn, and } \\
\text { feedstuff }\end{array}$ & [58] \\
\hline \multirow{3}{*}{ OTA } & $\begin{array}{l}\text { Random 7-mer } \\
\text { peptide library }\end{array}$ & $\mathrm{pIII}$ & GMVQTIF & $0.005-0.2 \mathrm{ng} / \mathrm{mL}$ & $0.1 \mathrm{ng} / \mathrm{mL}$ & Competitive ELISA & Corn & [32] \\
\hline & $\begin{array}{l}\text { Second generation } \\
\text { peptide library }\end{array}$ & pIII & AETYGFQLHAMK & $0.006-0.245 \mathrm{ng} / \mathrm{mL}$ & $0.005 \mathrm{ng} / \mathrm{mL}$ & Chemiluminescent ELISA & Corn, rice, and instant coffee & [56] \\
\hline & $\begin{array}{l}\text { Ph.D. }{ }^{\mathrm{TM}} \text {-7 phage } \\
\text { display peptide library }\end{array}$ & pIII & IRPMVXX & $200-8000 \mathrm{pg} / \mathrm{mL}$ & $150 \mathrm{pg} / \mathrm{mL}$ & Competitive ELISA & - & [59] \\
\hline \multirow{2}{*}{ ZEN } & $\begin{array}{c}\text { Ph.D.TM-7 Phage } \\
\text { Display Peptide Library }\end{array}$ & $\mathrm{pIII}$ & $\begin{array}{l}\text { DAVILLM; } \\
\text { HHCHWWH }\end{array}$ & $100-10,000 \mathrm{pg} / \mathrm{mL}$ & $100 \mathrm{pg} / \mathrm{mL}$ & Competitive ELISA & Wheat, corn, and feedstuff & [34] \\
\hline & $\begin{array}{l}\text { Random 12-mer } \\
\text { peptide library }\end{array}$ & $\mathrm{pIII}$ & ESYWATVPWTRH & $50-100 \mu \mathrm{g} / \mathrm{kg}$ & - & Dot-immunoassay & Peanut, corn and rice & [60] \\
\hline \multirow[b]{2}{*}{$\mathrm{FB}_{1}$} & $\begin{array}{l}\text { Ph.D.-C7C phage } \\
\text { display peptide library }\end{array}$ & $\mathrm{pIII}$ & E-L-P-T-L & $1.77-20.73 \mathrm{ng} / \mathrm{mL}$ & $1.18 \mathrm{ng} / \mathrm{mL}$ & $\begin{array}{l}\text { Chemiluminescent } \\
\text { Immunoassay }\end{array}$ & $\begin{array}{l}\text { Maize, feedstuff, } \\
\text { and wheat }\end{array}$ & [61] \\
\hline & $\begin{array}{l}\text { Random 12-mer } \\
\text { peptide library }\end{array}$ & $\mathrm{pIII}$ & $\begin{array}{l}\text { NNAAMYSEMATD; } \\
\text { TTLQMRSEMADD }\end{array}$ & - & $0.21 \mathrm{ng} / \mathrm{mL}$ & Elispot Immunoassay & Maize, feedstuff, and rice & [62] \\
\hline Phomopsin & $\begin{array}{l}\text { Random 15-mer phage } \\
\text { display peptide library }\end{array}$ & pIII & CTVALCNMYFGAKLD & - & - & Competitive ELISA & Lupin seed & [64] \\
\hline
\end{tabular}


Moreover, several methodologies have been successfully developed for small moleculepeptide/protein interaction studies based on the inter-disciplinary of biology, chemistry, physics, etc. For example, through detecting changes of the surface plasma signal excited by polarized light before and after binding to the immobilized molecule, surface plasma resonance (SPR) $[65,66]$ can be most popularly applied for the affinity conformation between peptides and small molecules. In addition, circular dichroism (CD), isothermal calorimetry (ITC), and docking simulation are also utilized [67-70].

\subsection{Random Peptide-Based Mycotoxins Detection}

Compared with other analytic methods, immunoassays have several advantages for rapid test, including higher sensitivity, stronger specificity, facile sample preparation, and ease of use. As one of immunoassays, ELISA has been used widely for mycotoxin detection following the development of monoclonal and polyclonal antibodies. However, the low efficiency of chemical conjugation of mycotoxins to a carrier protein may result in substantial bridge group interference and cross-reactions [31]. So protein or peptide mimics as immunochemical reagents have been developed as one possible alternative of mycotoxins.

Due to the tiny size, random peptides against a special mycotoxin or antibody cannot be directly immobilized on the solid surface for immunoassay, except in one report where the synthetic peptide alone was sufficient for binding to the antibody [31]. Actually, random peptides were always conjugated with some proteins to form fusion proteins using for immunoassays. The most direct way, M13 bacteriophage displayed with target peptides were used as coating antigens. For example, one mimotope peptide P3 (HPSDPRH), the $\mathrm{AFB}_{1}$ mimotope peptide, was obtained from Ph.D. ${ }^{\mathrm{TM}}$-7 Phage Display Peptide Library [58]. The recombinant phage was applied for the detection of $\mathrm{AFB}_{1}$ through an indirect competitive ELISA. Compared with a conventional indirect competitive ELISA with the $\mathrm{AFB}_{1}$-BSA conjugate, there was no special difference between ELISA methods in accuracy and precision. Similarly, for another example, 5 mimotopes against MAb 24 specific to aflatoxins $\mathrm{B}_{1}$ were identified from a random 8-peptide library [33]. The whole phage displayed with mimotope peptides were also used in an indirect competitive ELISA for analyzing total aflatoxin concentration with an $\mathrm{IC}_{50}$ value of $14 \mu \mathrm{g} / \mathrm{kg}$ and the linear range of $4-24 \mu \mathrm{g} / \mathrm{kg}$ (Figure 2A). Moreover, phage-based dot-immunoassay device based on PVDF membrane strips were also developed and acted as alternatives of 96-well plate [60].

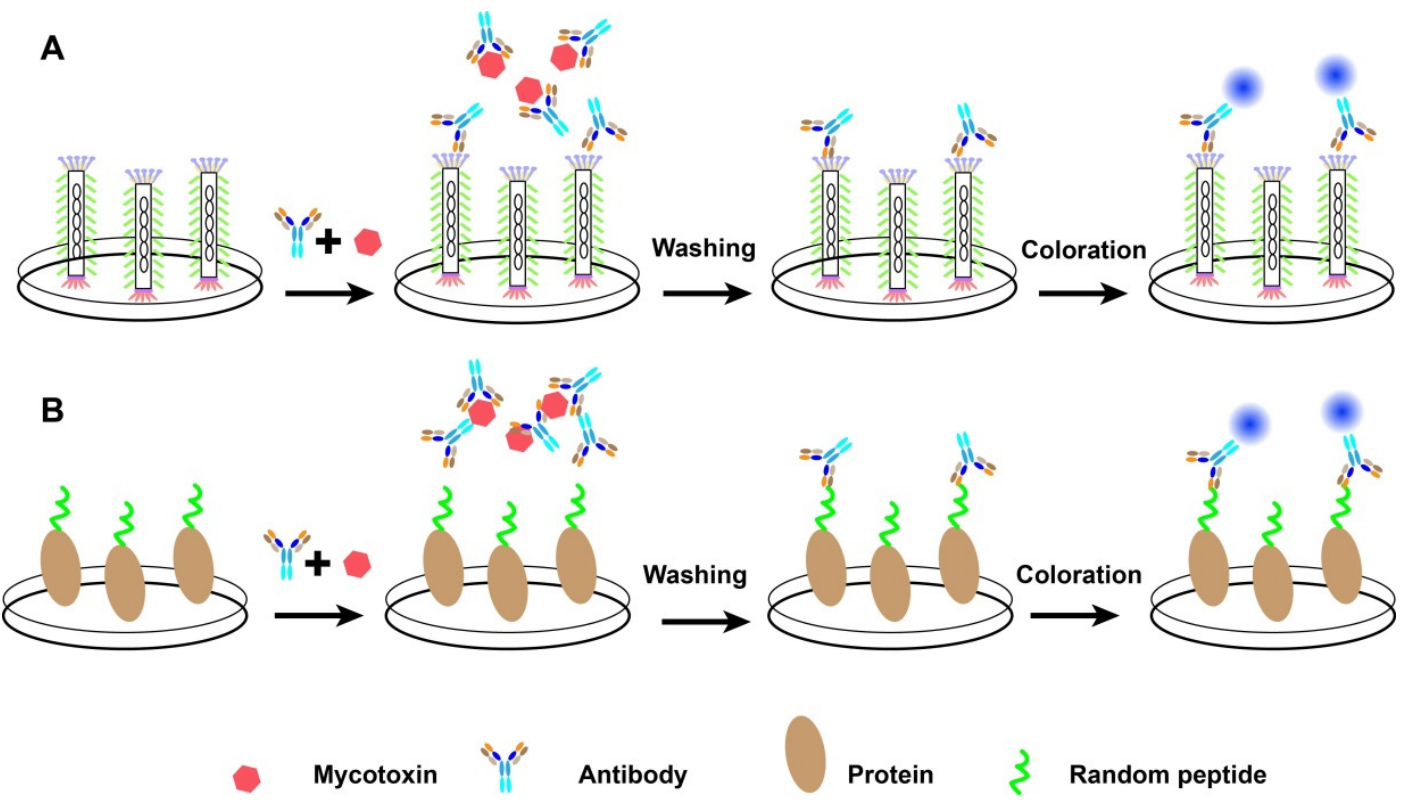

Figure 2. The process of competitive immunoassays based on phage form (A) or peptide fusion protein (B). 
However, phage-based immunoassays were not suitable for diagnosis due to the following reasons: (1) Phages with filamentous nature are "unconventional" reagents which can infect E. coli. (2) Peptide linked to the phage particles leads to complex difficulties in measuring the phage displayed peptide and quality control. (3) Peptide concentration was not controlled precisely, with the avidity artifacts associated with pentavalent display on the phage [22]. So mimotope conjugated with special proteins named fusion proteins were prepared and used as coating antigens in the immunoassay for analyzing mycotoxins (Figure 2B). For example, a phage clone that recognized anti-fumonisin McAb 1D11 from a phage random loop constrained heptapeptide library was selected as mimotope peptide and conjugated with bovine serum albumin as coating antigen [61]. The results for fumonisin detection showed that the linear range of the inhibition curve was $1.77-20.73 \mathrm{ng} / \mathrm{mL}$ and the limit of detection was $1.18 \mathrm{ng} / \mathrm{mL}$. In another example, phage displayed peptide which bind to ani- $\mathrm{FB}_{1}$ antibody from a 12-mer peptide library was selected and conjugated with maltose binding protein (MBP) to form fusion protein [62]. The fusion protein was used as a coating antigen to develop a qualitative Elispot assay with a cutoff level of $2.5 \mathrm{ng} / \mathrm{mL}$, and the results was 10-fold more sensitive than that of measurement from chemically synthesized $\mathrm{FB}_{1}$-BSA conjugates based Elispot immunoassay. In addition, an on-chip binding inhibition assay based on A2 peptide (VTPNDDTFDPFR) conjugated with biotin was developed for the detection of $\mathrm{FB}_{1}$ through microassay [63].

Beyond that, colloidal gold strip as a rapid and inexpensive detection method was also used for rapid detection of mycotoxins with the help of mimotope peptide. Lai et al. [71] developed a colloidal gold strip using chemically synthesized gold nanoparticles conjugated with anti-OTA monoclonal antibodies and the OTA mimotope was screened from a Ph.D. ${ }^{\mathrm{TM}}-7$ phage display peptide library. The results revealed that $10 \mathrm{ppb}$ of OTA was detected in $10 \mathrm{~min}$, which provides a rapid method without using the mycotoxin.

\section{Recombinant Antibody Using for Mycotoxins Detection}

\subsection{Recombinant Antibody Libraries}

Recently, the recombinant antibodies devoid of light chain have emerged as a salient alternative for immunosensing. Compared with conventional antibodies, the recombinant antibodies are smaller, such as antigen binding fragment (Fab), heavy chain only antibody $(\mathrm{HcAb})$, single chain fragment variable ( $\mathrm{scFv}$ ) and a single domain heavy chain antibody (VHH, termed "nanobody", Figure 3). Specially, the recombinant antibodies are particularly apt for genetic manipulation such as large-scale amplification and antibody-protein fusion to create bi-functional molecules [72]. Depending on the preparation method, there are mainly two types of recombinant antibody libraries, naive libraries and immune libraries.

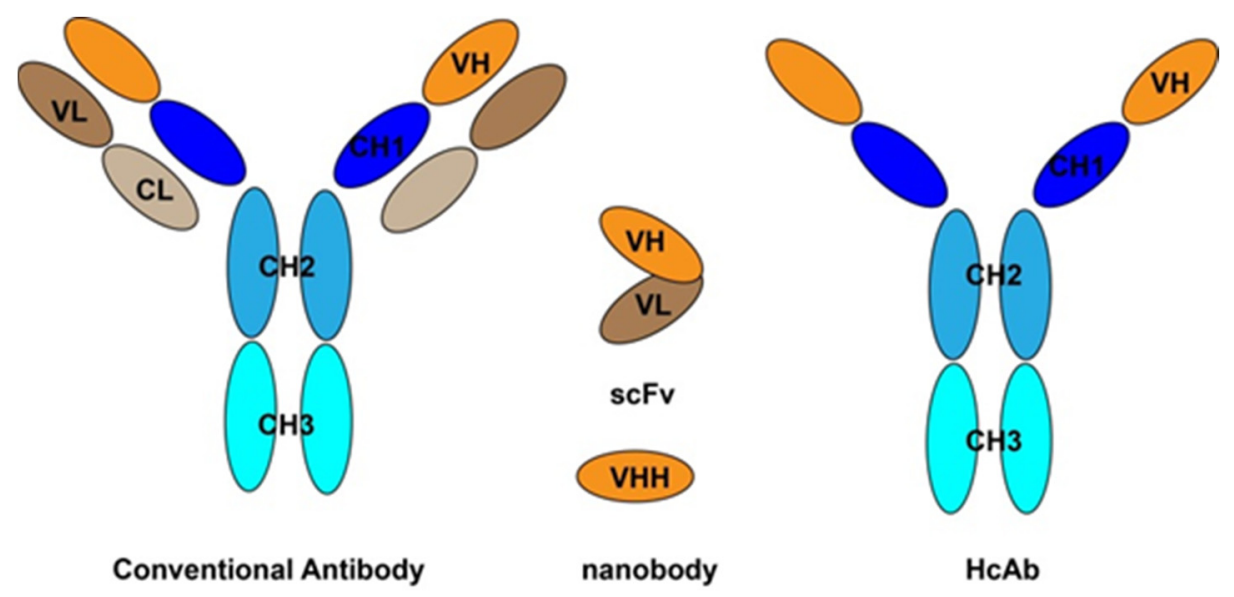

Figure 3. Different types of recombinant antibodies compared with conventional antibody.

Naive libraries are created from rearranged variable region $(\mathrm{V})$ gene pools of a nonimmunized individual [39]. Without immunity, the antibody structure, codon usage, and 
sequence diversity of naive libraries can be designed as desired. Most importantly, the library is not biased to small antigens. Additionally, good-quality antibodies against conserved antigens were also yielded from naive libraries [73]. In addition, high-affinity antibodies against mycotoxins have been isolated from naive libraries, such as $\mathrm{AFB}_{1}$, citrinin (CIT), ZEN, and DON [23,74-77]. However, for some special application, antibodies from naive libraries showed lower affinity, so immune libraries are generated by amplification variable region (V) genes of antibody extracted from plasma cells from immunized donors. Primarily, animals were immunized with target antigens for the isolation of recombinant antibodies. Subsequently, RNA extracted from spleen cells was transcribed into complementary DNA. Finally, a recombinant library was constructed through amplifying antibodies genes into appropriate vector. Overall, the above types of libraries are typically created to obtain an antibody for a specific target (Table 2) [78].

\subsection{ScFv Antbibodies Based-Detection Method}

The $\mathrm{scFv}$ first developed in 1988 is a recombinant protein composed of a variable region of heavy chain (VH) and a variable region of light chain (VL) of the antibody through a short peptide $[79,80]$. Due to the small molecular weight, strong penetration, and high affinity, scFv has been widely used in tumor therapy, infectious disease prevention and treatment, food safety residue detection, as well as other fields [81]. Without phage display, scFv can be generated from spleen cells directly and many of them have been prepared for mycotoxins detection, such as $\mathrm{FB}_{1}, \mathrm{ZEN}, \mathrm{DON}$, and CIT [82-85]. The scFv generated from phage recombinant antibody library were focus on the $\mathrm{AB}_{1}$ detection. For example, through biopanning to immobilized $\mathrm{AFB}_{1}$-BSA conjugate, two scFv fragments named YM1 C3 and TomI-F6 were generated from non-immunized Yamo 1 library and semisynthetic libraries (Tomlinson I \& J). After analysis of binding sensitivity by competitive ELISA, the $\mathrm{IC}_{50}$ of YM1 C3 and TomI-F6 was $0.04 \mu \mathrm{g} / \mathrm{mL}$ and $0.14 \mu \mathrm{g} / \mathrm{mL}$, respectively. Then, these two scFv DNA fragments were cloned into an AP expression vector to form scFvAP fusions, and the competitive ELISA results showed that the binding sensitivity of YM1 C3-AP $\left(\mathrm{IC}_{50}=0.034 \mu \mathrm{g} / \mathrm{mL}\right)$ is approximately 4 fold higher than that of TomI-F6-AP $\left(\mathrm{IC}_{50}=0.14 \mu \mathrm{g} / \mathrm{mL}\right)$. So the YM1 C3-AP was used as a convenient one-step detection probe for competitive ELISA of $\mathrm{AFB}_{1}$ [86]. For diagnosis, the affinity and sensitivity of selected $\mathrm{scFv}$ to mycotoxins is very important. Hence, a lot of efforts were made to increase its affinity and sensitivity. Through panning antibodies against $\mathrm{AFB}_{1}-\mathrm{BSA}$ and $\mathrm{AFB}_{1}$, Moghaddam et al. found many of the antibodies isolated specifically bound $\mathrm{AFB}_{1}-\mathrm{BSA}$, not soluble $\mathrm{AFB}_{1}$ or BSA [87]. At the same time, similar results were obtained by Chen et al. Compared to the selection against $\mathrm{AFB}_{1}$-bovine serum albumin conjugate, the isolated scFvs against $\mathrm{AFB}_{1}$ showed higher specificities for $\mathrm{AFB}_{1}$ [74]. Additionally, two highquality $\mathrm{scFv}$ antibodiesagainst $\mathrm{AFB}_{1}$ were isolated from synthesized immune scFv library using 20 hybridoma cell lines by Li et al. Thedis $\mathrm{IC}_{50}$ of $1 \mathrm{~A} 7$ and $2 \mathrm{G} 7$ was $0.02 \mathrm{ng} / \mathrm{mL}$ and $0.01 \mathrm{ng} / \mathrm{mL}$, respectively [88]. Recently, antibody-ligand interactions were analyzed and improved by Rangnoi et al. through chain-shuffling technique using a naive human phage-displayed scFv library and a constructed VH/VL chain-shuffled library. One clone named sAFH-3e3 showing 7.5-fold improvement in sensitivity was obtained [89]. 
Table 2. Recombinant antibodies and their performances in immunoassay applications.

\begin{tabular}{|c|c|c|c|c|c|c|c|c|}
\hline Mycotoxin & $\begin{array}{c}\text { Antibody } \\
\text { Type }\end{array}$ & Library & $\begin{array}{l}\text { Linear } \\
\text { Range }\end{array}$ & LOD & $\mathrm{IC}_{50}$ & $\begin{array}{l}\text { Detection } \\
\text { Principle }\end{array}$ & $\begin{array}{l}\text { Sample } \\
\text { Matrices }\end{array}$ & Ref. \\
\hline $\mathrm{FB}_{1}$ & $\mathrm{scFv}$ & VHH library & $2.10-76.45 \mu \mathrm{g} / \mathrm{L}$ & $8.32 \mu \mathrm{g} / \mathrm{kg}$ & $12.67 \mu \mathrm{g} / \mathrm{L}$ & Competitive ELISA & Corn & [82] \\
\hline ZEN & $\mathrm{scFv}$ & VHH library & - & - & $17 \mathrm{ng} / \mathrm{mL}$ & Competitive ELISA & Corn & [83] \\
\hline $\mathrm{DON}$ & $\mathrm{scFv}$ & - & - & - & $8.2 \pm 0.6 \mathrm{ng} / \mathrm{mL}$ & Competitive ELISA & Wheat & [84] \\
\hline CIT & $\mathrm{scFv}$ & Mutational phage library & $25-562 \mu \mathrm{g} / \mathrm{mL}$ & $14.7 \mathrm{ng} / \mathrm{mL}$ & $120 \mathrm{ng} / \mathrm{mL}$ & Competitive ELISA & Corn & [85] \\
\hline $\mathrm{AFB}_{1}$ & $\mathrm{scFv}$ & Human non-immunized scFv library & $0.007-0.2 \mu \mathrm{g} / \mathrm{mL}$ & $0.007 \mu \mathrm{g} / \mathrm{mL}$ & $0.034 \mu \mathrm{g} / \mathrm{mL}$ & Competitive ELISA & - & [86] \\
\hline $\mathrm{AFB}_{1}$ & $\mathrm{scFv}$ & Naive recombinant antibody libraries & - & - & & Competitive ELISA & - & [87] \\
\hline $\mathrm{AFB}_{1}$ & $\mathrm{scFv}$ & Tomlinson libraries I + J & & & $0.4 \mathrm{ng} / \mathrm{mL}$ & Competitive ELISA & & [74] \\
\hline $\mathrm{AFB}_{1}$ & $\mathrm{scFv}$ & positive phage-display library & - & - & $0.01 \mathrm{ng} / \mathrm{mL}$ & Competitive ELISA & - & [88] \\
\hline CIT & VHH & $\begin{array}{l}\text { Naive alpaca phage displayed } \mathrm{VHH} \\
\text { library }\end{array}$ & 5-300 ng/mL & $\begin{array}{l}7.6 \mu \mathrm{g} / \mathrm{kg} \\
8.6 \mu \mathrm{g} / \mathrm{kg}\end{array}$ & $44.6 \mathrm{ng} / \mathrm{mL}$ & VHH-based ELISA & $\begin{array}{l}\text { Wheat, } \\
\text { Rice }\end{array}$ & [75] \\
\hline OTA & $\mathrm{VHH}$ & - & $0.003-0.673 \mathrm{ng} / \mathrm{mL}$ & $0.001 \mathrm{ng} / \mathrm{mL}$ & $0.097 \mu \mathrm{g} / \mathrm{mL}$ & Competitive ELISA & Corn, rice, wheat & [90] \\
\hline OTA & $\mathrm{VHH}$ & VHH Library & $0.01-1000 \mathrm{pg} / \mathrm{mL}$ & $3.7 \mathrm{pg} / \mathrm{L}$ & $0.31 \mathrm{ng} / \mathrm{mL}$ & PD-IPCR & Corn, wheat, rice & [91] \\
\hline OTA & $\mathrm{VHH}$ & - & $0.06-0.43 \mathrm{ng} / \mathrm{mL}$ & $0.04 \mathrm{ng} / \mathrm{mL}$ & $0.13 \mathrm{ng} / \mathrm{mL}$ & $\begin{array}{l}\text { Fluorescencecompetitive } \\
\text { ELISA }\end{array}$ & Rice, oats, barley & [92] \\
\hline 15-AcDON & $\mathrm{VHH}$ & VHH library & $10-5000 \mathrm{ng} / \mathrm{mL}$ & $19 \mathrm{ng} / \mathrm{mL}$ & $0.5 \mu \mathrm{M}$ & Competitive ELISA & - & [93] \\
\hline ZEN & $\mathrm{VHH}$ & $\begin{array}{l}\text { Naive alpaca phage displayed VHH } \\
\text { library }\end{array}$ & $0.11-0.55 \mathrm{ng} / \mathrm{mL}$ & $0.08 \mathrm{ng} / \mathrm{mL}$ & $0.25 \pm 0.02 \mathrm{ng} / \mathrm{mL}$ & PD-IPCR & Corn, wheat, rice & [76] \\
\hline
\end{tabular}




\subsection{Anti-Idiotypic Antibody Based-Detection Method}

Anti-idiotypic antibody is a secondary antibody that targets the idiotype of the primary antibody, which sit on the variable regions of immunoglobulins and possess specific antigenic determinants. Numerous anti-idiotypic antibodies against both large and small molecules have been developed and applied in diagnostics and immunoassays [94,95]. Interestingly, a type of antibody from camelids completely devoid of light chains (only heavy chain antibody) was found in 1993 [96]. The variable domain ( $\mathrm{VH})$ of such heavy chain antibodies is formed by only one variable domain ( $\mathrm{VHH})$, termed nanobody [97,98]. In virtue of small size, good physical and chemical properties, large scale in production, and easy manipulating, anti-idiotypic nanobodies have also been developed and used for diagnostic and therapeutic purposes [99,100].

Absolutely, anti-idiotypic antibodies were also applied in environmental immunoassays, including mycotoxins diagnostic. The first research using nanobodies for mycotixins detection was reported by Wang et al. In their work, the authors constructed an antibody phage library from the mRNA of an alpaca immunized with an anti-aflatoxin monoclonal antibody (MAb) 1C11 and isolated VHH antibodies, which applied to immunoassay towards aflatoxin as a coating antigen. The immunoassay with an $\mathrm{IC}_{50}$ of $0.16 \mathrm{ng} / \mathrm{mL}$ showed a good correlation $\left(R^{2}=0.89\right)$ towards the conventional ELISA method [78]. Normally, anti-idiotypics nanobodies mimics, selected from recombinant antibodies library or naive antibodies library, were acted as surrogate antigens which can competitively bind with homologous antibodies. Then the unbound antibodies with mycotoxins were captured by the pre-coated nanobodies and detected such as CIT, OTA, 15-acetyl-deoxynivalenol (15-acDON), ZEN [76,80,91-94].

Besides competing immunoassay, other methods based on nanobodies were also developed. For instance, phage display-mediated immuno-polymerase chain reaction (PD-IPCR), a highly promising technique for ultrasensitive analysis of small molecules, was first described by Zhang et al. and has been applied for mycotoxins detection [101]. As signal output, PD-IPCR has been reported for ultrasensitive analysis of antigens combining nanobodies with phage DNA, including noncompetitive phage anti-immuno complex real-time (RT) PCR [102], phage-based open-sandwich immune-PCR [103] and competitive phage real-time PCR. For example, Liu et al. [91] constructed an alpaca-derived heavychain antibodies (VHH) library and obtained the clone-28 which showed the lowest 50\% inhibitory concentration. Then, the VHH phage-based RT immuno-PCR was developed and utilized for the analysis of OTA (detailed process illustrated in Figure 4). The results displayed that detection limit of the VHH phage-based RT immuno-PCR was $3.7 \mathrm{pg} / \mathrm{L}$ with a linear range of $0.01-1000 \mathrm{pg} / \mathrm{mL}$, indicating the reliability of $\mathrm{VHH}$ phage-based RT-IPCR in the detection of OTA in cereal samples. In the same way, anti-idiotypic VHH PD-PCR was also supplied for ultrasensitive determination of mycotoxin zearalenone in cereals. Compared with phage ELISA, the LOD of Z1 (anti-idiotypic VHH phage clone) based PD-IPCR was 12-fold improved, together with a detection limit of $6.5 \mathrm{pg} / \mathrm{mL}$ and a linear range of $0.01-100 \mathrm{ng} / \mathrm{mL}$ [76]. However, PD-IPCR method needs special instrument (Real time fluorescence quantitative PCR instrument) and a longer assay time (more than $3 \mathrm{~h}$ ), and it is not suitable for on-site fast detection of mycotoxins.

As an alternative to PCR based analysis, the loop-mediated isothermal amplification (LAMP) is an innovative technique for rapid and easy detection of target nucleic acids. Since first reported in 2000, LAMP has been applied in various fields of diagnosis, such as pathogen detection and disease diagnosis [104-106]. Due to the higher specificity and efficiency, on-site testing, naked eye identification, and isothermal amplification, immune-LAMP (iLAMP) assay was exploited for aflatoxin detection. The basic process is as follows (Figure 5): Firstly, anti-aflatoxin $\mathrm{mAb} 1 \mathrm{C} 11$ was pre-coated on the bottom of a PCR tube. Secondly, the sample extract and nanobody-phage V2-5 were added to the tube simultaneously with a competition binding between the phage and aflatoxin to $\mathrm{mAb} 1 \mathrm{C} 11$. Subsequently, the unbound phages were washed away after the incubation. Finally, the LAMP solutions were added into the tube for amplification for visual detection. The color 
of violet and sky blue respectively means positive and negative result. The visual detection limits of iLAMP of $\mathrm{AFB}_{1}, \mathrm{AFB}_{2}, \mathrm{AFG}_{1}$, and $\mathrm{AFG}_{2}$ in peanut samples were 1.6, 1.6, 3.2, and $16 \mu \mathrm{g} / \mathrm{kg}$, respectively [107].

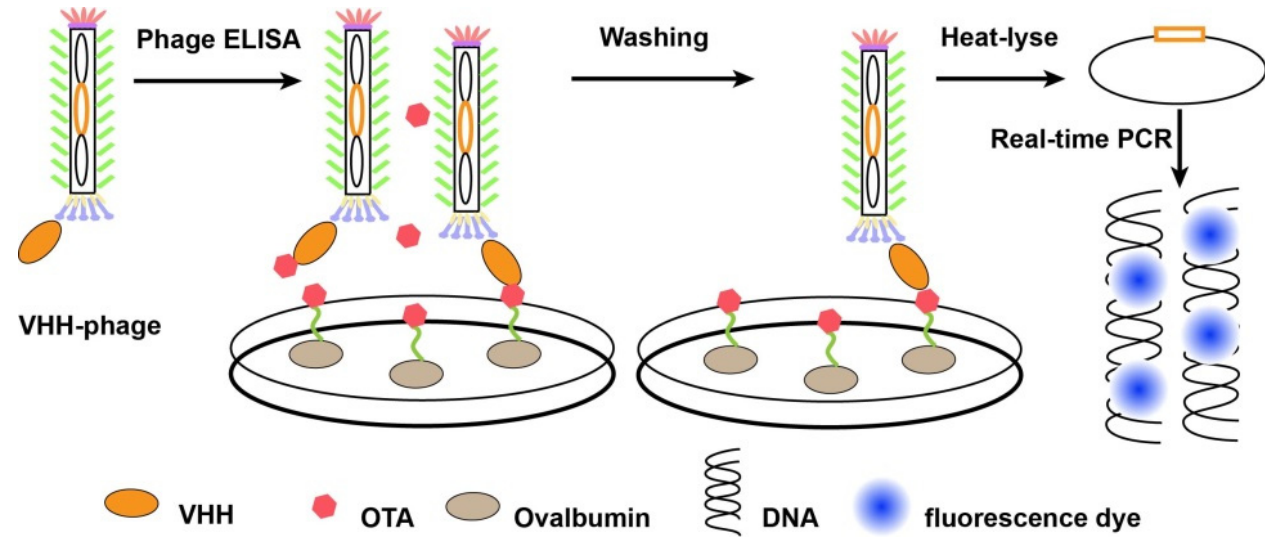

Figure 4. The process of PD-IPCR based on VHH-phage. Firstly, VHH-phages and OTA were mixed and incubated with ovalbumin conjugated OTA pre-coated on the solid surface. Then, VHH-phages binding with OTA were washed out and redundant VHH-phages were fixed. Finally, the DNA of VHH-phages were released by heat-lyse and used as templates of real-time PCR.

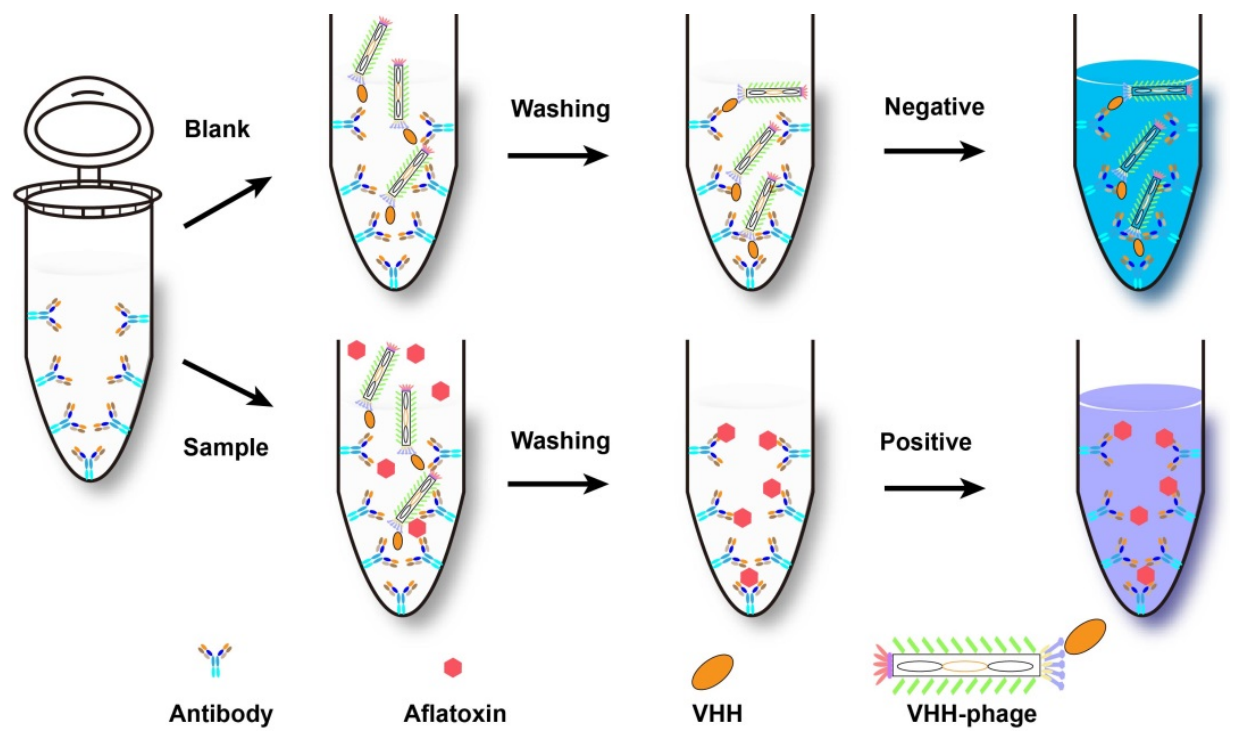

Figure 5. The detailed process of iLAMP assay (adapted from [107]).

\section{Simultaneous Determination of Multiplex Mycotoxins}

Currently, many techniques have been developed to quantitatively or qualitatively detect multiple mycotoxins, including chromatographic techniques, immunochemical assays and electrochemical techniques [108-112]. For example, with the help of different mycotoxin or antibody conjugated fluorescent nanoparticles, multiplexed immunochromatographic assay (mICA) strips were widely developed for the simultaneous monitoring of multiple mycotoxins, such as gold nanoparticles [113,114], quantum dot microbeads [115], and amorphous carbon nanoparticles [116]. In the following sections, different multiplex immumoassay of mycotoxins using peptide mimotope or recombinant antibodies are presented.

\subsection{Random Peptide-Based Multiplex Detection}

Due to rapidity, good specificity, high throughput, convenience and low cost, ICA is the most commonly used and mature screening platforms for on-site determinations. ICA requires only the addition of the sample initiating a series of reactions which result 
in a readable signal. ICA had been developed for singleplex and multiplex detection based on traditional antibodies [117-123]. Recently, a multiplex ICA based on random peptides was developed for detection of three different mycotoxins. Yan et.al developed an economical and sensitive QDs and QBs based mICA for the rapid detection of $\mathrm{FB}_{1}$, ZEN, and OTA without the building-up process of mycotoxin conjugates [19]. QBs conjugated with anti-FB 1 mAb or anti-ZEN mAb, and QDs coupled with anti-OTA mAb, were selected as fluorescent reporters. Furthermore, phage-displayed $\mathrm{FB}_{1}, \mathrm{ZEN}$ and OTA mimotope peptide were monovalently fused to MBP, which were applied onto the test line of the mICA as the mimetic coating antigen. The immunochromatograghic test is applied with the competition between mycotoxins in the sample and peptide mimics. The visual detection limits of peptide-MBP-based mICA could be obtained as $0.25 \mathrm{ng} / \mathrm{mL}$ for $\mathrm{FB}_{1}, 3.0 \mathrm{ng} / \mathrm{mL}$ for ZEN, and $0.5 \mathrm{ng} / \mathrm{mL}$ for OTA within $10 \mathrm{~min}$. The proposed mICA was comparable with UPLC-MS in terms of reliability in detecting $\mathrm{FB}_{1}$, ZEN and OTA.

\subsection{Recombinant Antibodies-Based Multiplex Detection}

\subsubsection{Time-Resolved Fluorescence Immunochromatographic Assay}

Time-resolved fluorescence, which used lanthanides as tracers, has a longer fluorescence lifetime that could eliminate the background interference, thus achieving more sensitive and specific assays. Tang et al. prepared a novel $\mathrm{Eu} / \mathrm{Tb}$ (III) nanosphere with enhanced fluorescence conjugated to anti-idiotypic nanobody and established a competitive time-resolved strip method for rapid, quantitative, and simultaneous detection of aflatoxin and zearalenone in maize and its products. The results showed that the half inhibition concentration was 0.46 and $0.86 \mathrm{ng} / \mathrm{mL}$ for $\mathrm{AFB}_{1}$ and $\mathrm{ZEN}$, and the detection limit was 0.05 and $0.07 \mathrm{ng} / \mathrm{mL}$, respectively [124].

\subsubsection{Duplex Real-Time PCR Methods}

As demonstrated above, PD-IPCR has been an ultrasensitive immunoassay for mycotoxins detection. Through the combination of PD-IPCR and RT-PCR, a new detection platform was developed for simultaneously detecting of aflatoxins and Aspergillus section Flavi in stored maize. The quantitative standard curves for simultaneous detection of aflflatoxins and Aspergillus section Flavi were constructed, with detection limits of $0.02 \mathrm{ng} / \mathrm{mL}$ and $8 \times 10^{2}$ spores $/ \mathrm{g}$, respectively. The entire process for the simultaneous detection requires less than 1 day. Therefore, this detection platform provides new ideas for simultaneous detection of small molecular contaminants and microorganisms [125].

\section{Conclusions}

Mycotoxins are small size secondary metabolites of fungi, which pose a threat to the safety of medicine, food and public health. Many novel methods have been developed for mycotoxins detection, such as antibodies and aptamers [126]. M13 bacteriophage has also been applied for screening mimotopes of small analytes including mycotoxins as target recognition element.

In the bio-panning of mimitopes, random peptides library and recombinant antibodies library were separately constructed with M13 phage display technology and applied to select desired surrogate antigens or antibodies. It should be noted that both libraries have their own advantages and disadvantages in the application, and a better choice should be made according to our own situation. Random peptide library can mimic continuous or discontinuous (distant in the primary sequence but close in the folded native conformation) determinants on ligands that specifically bind receptors or other proteins, and even nonproteinaceous ligands. Random peptide library shows no bias to small antigens, which makes it a good choice for mycotoxins detection. However, the peptides from random peptide library may show lower affinity, and recombinant antibody library will be a better choice because the recombinant antibodies generated from immune donors inherently have good affinities. Furthermore, after bio-panning, the recombinant antibody with the highest affinity can be successfully isolated. 
In the application, individual peptides or phage form were rarely used. Instead, random peptides were always conjugated with other proteins to form fusion proteins and then applied for mycotoxins detection. Beyond that, with the help of multi-functional phage display technology, a versatile biosensor based on M13 phage has been assembled for detection analysis. For example, M13 phage was decorated with different mimotopes on the tip and backside of phage bodies, which endows it new features, such as the targeting bound capacity, the optical property of quantum dot, the accumulation of magnetic nanoparticle, and so on [127]. Compared with random peptides, recombinant antibodies can be directly immobilized on the solid surface to bind with antigens. So many recombinant antibodies, including scFvs and anti-idiotypic antibodies were isolated from recombinant antibody libraries and applied for sensitive diagnosis of various mycotoxins through ELISA, PD-IPCR and iLAMP, etc. Meanwhile, novel immunoregents using for the detection of different congeners from a mycotoxin group might be generated through recombinant antibodies in the future. This may be beneficial to detect broad range of mycotoxins. What is more delightful is that simultaneous detection of mycotoxins was developed based on the phage display. To some extent, all these results demonstrated the advantages of recombinant antibody in stronger specificity, higher sensitivity, less time consuming, and superior safety. However, there are still some challenges to select interested mimotopes binding to small molecule epitopes. This hampers the more extensive applications of phage display in mycotoxin detection. Therefore, efforts should be made to cope with the difficulties in the future.

Author Contributions: Conceptualization, W.S. and Z.J.; supervision, Z.J.; writing—original draft preparation, W.S. and Y.Z.; writing - review and editing, W.S. All authors have read and agreed to the published version of the manuscript.

Funding: This research was funded by National Natural Science Foundation of China, grant number 81703700 and Guizhou Science and Technology Project, grant number [2019]1019.

Conflicts of Interest: The authors declare no conflict of interest.

\section{References}

1. Peraica, M.; Radić, B.; Lucić, A.; Pavlović, M. Toxic effects of mycotoxins in humans. Bull. World Health Organ. 1999, 77, 754. [PubMed]

2. Hussein, H.S.; Brasel, J.M. Toxicity, metabolism, and impact of mycotoxins on humans and animals. Toxicology 2001, 167, 101-134. [CrossRef]

3. Anfossi, L.; Giovannoli, C.; Baggiani, C. Mycotoxin detection. Curr. Opin. Biotechnol. 2016, 37, 120-126. [CrossRef] [PubMed]

4. Majdinasab, M.; Ben Aissa, S.; Marty, J.L. Advances in Colorimetric Strategies for Mycotoxins Detection: Toward Rapid Industrial Monitoring. Toxins 2020, 13, 13. [CrossRef] [PubMed]

5. Chena, F.; Luana, C.; Lin, W.; Shue, W.; Shao, L. Simultaneous determination of six mycotoxins in peanut by high-performance liquid chromatography with a fluorescence detector. J. Sci. Food Agric. 2017, 97, 1805-1810. [CrossRef] [PubMed]

6. Zhang, Y.; Pei, F.; Fang, Y.; Li, P.; Zhao, Y.; Shen, F.; Zou, Y.; Hu, Q. Comparison of concentration and health risks of 9 fusarium mycotoxins in commercial whole wheat flour and refined wheat flour by multi-IAC-HPLC. Food Chem. 2019, 275, 763-769. [CrossRef] [PubMed]

7. Yelko, R.C.; Juan, C.M.; Houda, B.; Jordi, M. A survey of trichothecenes, zearalenone and patulin in milled grain-based products using GC-MS/MS. Food Chem. 2014, 146, 212-219.

8. Yelko, R.C.; Juan, C.M.; Jordi, M.; Houda, B. Defvelopment of a GC-MS/MS strategy to determine 15 mycotoxins and metabolites in human urine. Talanta 2014, 128, 125-131.

9. Kim, E.S.; Chris, R.T.; Stephanie, F.; Martin, H.M.; Michael, E.L.; Chris, M.M.; Lisa, C.S. Indirect competitive immunoassay for detection of aflatoxin $\mathrm{B}_{1}$ in corn and nut products using the array biosensor. Biosens. Bioelectron. 2006, 21, $2298-2305$.

10. Pöhlmann, C.; Elßner, T. Multiplex immunoassay techniques for on-Ssite detection of security sensitive toxins. Toxins 2020, 12, 727. [CrossRef] [PubMed]

11. Pensuda, S.; Natcha, P.; Kuntalee, R.; Kiattawee, C.; Montarop, Y. Generation of human and rabbit recombinant antibodies for the detection of Zearalenone by phage display antibody technology. Talanta 2019, 201, 397-405.

12. Wang, J.; Mukhtar, H.; Ma, L.; Pang, Q.; Wang, X.H. VHH antibodies: Reagents for mycotoxin detection in food products. Sensors 2018, 18, 485. [CrossRef] [PubMed]

13. Saeed, A.F.; Wang, R.Z.; Ling, S.M.; Wang, S.H. Antibody engineering for pursuing a healthier future. Front. Microbiol. 2017, 8, 495. [CrossRef] [PubMed] 
14. Jerne, N.K. Towards a network theory of the immune system. Ann. Immunol. (Paris) 1974, 125C, 373-389. [PubMed]

15. Peltomaa, R.; Barderas, R.; Benito-Peña, E.; Moreno-Bondi, M.C. Recombinant antibodies and their use for food immunoanalysis. Anal. Bioanal. Chem. 2021, 1-25. [CrossRef] [PubMed]

16. Uhlen, M.; Bandrowski, A.; Carr, S.; Edwards, A.; Ellenberg, J.; Lundberg, E.; Rimm, D.; Rodriguez, H.; Hiltke, T.; Snyder, M.; et al. A proposal for validation of antibodies. Nat. Methods 2016, 13, 823-827. [CrossRef] [PubMed]

17. Peltomaa, R.; Agudo-Maestro, I.; Más, V.; Barderas, R.; Benito-Peña, E.; Moreno-Bondi, M.C. Development and comparison of mimotope-based immunoassays for the analysis of fumonisin $B_{1}$. Anal. Bioanal. Chem. 2019, 411, 6801-6811. [CrossRef]

18. Sheedy, C.; MacKenzie, C.R.; Hall, J.C. Isolation and affinity maturation of hapten-specific antibodies. Biotechnol. Adv. 2007, 25, 333-352. [CrossRef]

19. Yan, J.X.; Hu, W.J.; You, K.H.; Ma, Z.E.; Xu, Y.; Li, Y.P.; He, Q.H. Biosynthetic mycotoxin conjugate mimetics-mediated green strategy for multiplex mycotoxin immunochromatographic assay. J. Agric. Food Chem. 2020, 68, 2193-2200. [CrossRef]

20. Shua, M.; Xu, Y.; Wang, D.; Liu, X.; Li, Y.P.; He, Q.H.; Tu, Z.; Qiu, Y.L.; Ji, Y.W.; Wang, X.X. Anti-idiotypic nanobody: A strategy for development of sensitive and green immunoassay for fumonisin $B_{1}$. Talanta 2015, 143, 388-393. [CrossRef]

21. He, T.; Zhu, J.; Nie, Y.; Hu, R.; Wang, T.; Li, P.W.; Zhang, Q.; Yang, Y.H. Nanobody technology for mycotoxin detection: Current status and prospects. Toxins 2018, 10, 180. [CrossRef]

22. Kim, H.J.; McCoy, M.R.; Majkova, Z.; Dechant, J.E.; Gee, S.J.; Tabares-da Rosa, S.; González-Sapienza, G.G.; Hammock, B.D. Isolation of alpaca anti-hapten heavy chain single domain antibodies for development of sensitive immunoassay. Anal. Chem. 2012, 84, 1165-1171. [CrossRef] [PubMed]

23. Qiu, Y.L.; He, Q.H.; Xu, Y.; Bhunia, A.K.; Tu, Z.; Chen, B.; Liu, Y.Y. Deoxynivalenol-mimic nanobody isolated from a naive phage display nanobody library and its application in immunoassay. Anal. Chim. Acta 2015, 887, 201-208. [CrossRef] [PubMed]

24. Arap, W.; Kolonin, M.G.; Trepel, M.; Lahdenranta, J.; Cardó-Vila, M.; Giordano, R.J.; Mintz, P.J.; Ardelt, P.U.; Yao, V.J.; Vidal, C.I.; et al. Steps toward mapping the human vasculature by phage display. Nat. Med. 2002, 8, 121-127. [CrossRef] [PubMed]

25. Itay, M.; Tomer, S.; Nimrod, D.R.; Jonathan, M.G.; Eytan, R.; Roded, S.; Tal, P. Epitope mapping using combinatorial phage-display libraries: A graph-based algorithm. Nucleic Acids Res. 2007, 35, 69-78.

26. Cai, J.; Liu, Z.F.; Wang, F.; Li, F. Phage display applications for molecular imaging. Curr. Pharm. Biotechnol. 2010, 11, 603-609. [CrossRef]

27. Kamada, H.; Okamoto, T.; Kawamura, M.; Shibata, H.; Abe, Y.; Ohkawa, A.; Nomura, T.; Sato, M.; Mukai, Y.; Sugita, T.; et al. Creation of novel cell-penetrating peptides for intracellular drug delivery using systematic phage display technology originated from Tat transduction domain. Biol. Pharm. Bull. 2007, 30, 218-223. [CrossRef] [PubMed]

28. Ju, Z.G.; Sun, W. Drug delivery vectors based on filamentous bacteriophages and phage-mimetic nanoparticles. Drug Deliv. 2017, 24, 1898-1908. [CrossRef] [PubMed]

29. Sachdev, S.S.; Wayne, J.F.; Kurt, D. Exploring protein-protein interactions with phage display. Chembiochem 2003, 4, 14-25.

30. Catherine, L.B.; Amos, O.; Andrei, T.; Gali, P.; Sankar, A. A phage display system designed to detect and study protein-protein interactions. Mol. Microbiol. 2008, 67, 719-728.

31. Yuan, Q.P.; James, J.P.; Brandon, M.H.; Leslie, A.K.; John, E.L.; Hart, L.P. Identification of mimotope peptides which bind to the mycotoxin deoxynivalenol-specific monoclonal antibody. Appl. Environ. Microbiol. 1999, 65, 3279-3286. [CrossRef] [PubMed]

32. Zou, X.Q.; Chen, C.C.; Huang, X.L.; Chen, X.L.; Wang, L.; Xiong, Y.H. Phage-free peptide ELISA for ochratoxin A detection based on biotinylated mimotope as a competing antigen. Talanta 2016, 146, 394-400. [CrossRef] [PubMed]

33. Wang, Y.; Wang, H.; Li, P.; Zhang, Q.; Kim, H.J.; Gee, S.J.; Hammock, B.D. Phage-displayed peptides that mimic aflatoxins and its application in immunoassay. J. Agric. Food Chem. 2013, 61, 2426-2433. [CrossRef] [PubMed]

34. He, Q.H.; Xu, Y.; Huang, Y.H.; Liu, R.R.; Huang, Z.B.; Li, Y.P. Phage-displayed peptides that mimic zearalenone and its application in immunoassay. Food Chem. 2011, 126, 1312-1315. [CrossRef]

35. Speijers, G.J.A.; Speijers, M.H.M. Combined toxic effects of mycotoxins. Toxicol. Lett. 2004, 153, 91-98. [CrossRef] [PubMed]

36. Jong-Sik, M.; Eun, J.C.; Jeong, N.N.; Jong-Ryeul, S.; Han, D.W.; Oh, J.W. Research progress of M13 bacteriophage-based biosensors. Nanomaterials 2019, 9, 1448.

37. Kuzmicheva, G.A.; Belyavskaya, V.A. Peptide phage display in biotechnology and biomedicine. Biochem. Mosc.-Suppl. S 2017, 11, 1-15. [CrossRef]

38. Leila, R.; Safar, F.; Hossein, B.; Jafar, M.; Kamal, V.; Vahideh, A.; Bahman, A. Evolution of phage display technology: From discovery to application. J. Drug Target. 2016, 25, 216-224.

39. Kobra, O.; Maryam, D. Advances in phage display technology for drug discovery. Expert Opin. Drug Dis. 2015, 10, 651-669.

40. George, P.S. Filamentous fusion phage: Novel expression vectors that display cloned antigens on the virion surface. Science 1985, 228, 1315-1317.

41. George, P.S.; Valery, A.P. Phage Display. Chem. Rev. 1997, 97, 391-410.

42. Il'ichev, A.A.; Minenkova, O.O.; Tat'kov, S.I.; Karpyshev, N.N.; Eroshkin, A.M.; Petrenko, V.A.; Sandakhchiev, L.S. Production of a viable variant of the M13 phage with a foreign peptide inserted into the basic coat protein. Dokl. Akad. Nauk. SSSR 1989, 307, 481-483. 
43. Jespers, L.S.; Messens, J.H.; De, K.A.; Eeckhout, D.; Brande, I.; Gansemans, Y.G.; Lauwereys, M.J.; Stanssens, P.E. Surface expression and ligand-based selection of cDNAs fused to filamentous phage gene VI. Biotechnology 1995, 13, 378-382. [CrossRef] [PubMed]

44. Wang, Y.C.; Ju, Z.G.; Cao, B.R.; Gao, X.; Zhu, Y.; Qiu, P.H.; Xu, H.; Pan, P.T.; Bao, H.Z.; Wang, L.; et al. Ultrasensitive rapid detection of human serum antibody biomarkers by biomarker-capturing viral nanofibers. ACS Nano 2015, 9, 4475-4483. [CrossRef]

45. Devlin, J.J.; Panganiban, L.C.; Devlin, P.E. Random peptide libraries: A source of specific protein binding molecules. Science 1990, 249, 404-406. [CrossRef] [PubMed]

46. Hennie, R.H.; Adriaan, P.D.; Simon, E.H.; René, M.H.; Arends, J.W.; Roovers, R.C. Antibody phage display technology and its applications. Immunotechnology 1998, 4, 1-20.

47. Mark, R.H.; Luciano, M.; Arthur, P. Tunable alignment of macromolecules by filamentous phage yields dipolar coupling interactions. Nat. Struct. Biol. 1998, 5, 1065-1074.

48. Scott, J.K.; Smith, G.P. Searching for peptide ligands with an epitope library. Science 1990, 249, 386-390. [CrossRef]

49. Kehoe, J.W.; Kay, B.K. Filamentous phage display in the new millennium. Chem. Rev. 2005, 105, 4056-4072. [CrossRef] [PubMed]

50. Sharon, L.B.; Francis, J.S.; Alice, L.E.; Arnold, L.S. Peptides selected for binding to a virulent strain of Haemophilus influenzae by phage display are bactericidal. Antimicrob. Agents Chemother. 2005, 49, 2972-2978.

51. James, W.G.; Amanda, L.G.; Anatoliy, T.P.; Deepa, B.; Valery, A.P. Combinatorial synthesis and screening of cancer cell-specific nanomedicines targeted via phage fusion proteins. Front. Microbiol. 2015, 6, 628.

52. Mikhail, G.K.; Sun, J.; Kim-Anh, D.; Claudia, I.V.; Yuan, J.; Keith, A.B.; Renata, P.; Wadih, A. Synchronous selection of homing peptides for multiple tissues by in vivo phage display. FASEB J. 2006, 20, 979-981.

53. Renata, P.; Erkki, R. Organ targeting In vivo using phage display peptide libraries. Nature 1996, 380, $364-366$.

54. Saggy, I.; Yariv, W.; Leeron, S.C.; Limor, N.; George, G.; Itai, B. Antibody isolation from immunized animals: Comparison of phage display and antibody discovery via V gene repertoire mining. Protein Eng. Des. Sel. 2012, 25, 539-549. [CrossRef] [PubMed]

55. Andrew, C.; Bergquist, P.L.; Anwar, S. Solid-binding peptides in biomedicine. Adv. Exp. Med. Biol. 2017, 1030, 21-36.

56. He, Z.Y.; He, Q.H.; Xu, Y.; Li, Y.P.; Liu, X.; Chen, B.; Lei, D.; Sun, C.H. Ochratoxin A mimotope from second-generation peptide library and its application in immunoassay. Anal. Chem. 2013, 85, 10304-10311. [CrossRef]

57. Thirumala-Devi, K.; Miller, J.S.; Reddy, G.; Reddy, D.V.R.; Mayo, M.A. Phage-displayed peptides that mimic aflatoxin B ${ }_{1}$ in serological reactivity. J. Appl. Microbiol. 2001, 90, 330-336. [CrossRef]

58. Liu, R.R.; Xu, L.; Qiu, X.M.; Chen, X.L.; Deng, H.L.; Lai, W.H.; Xu, Y. An immunoassay for determining aflatoxin $B_{1}$ using a recombinant phage as a nontoxic coating conjugate. J. Food Saf. 2012, 32, 318-325. [CrossRef]

59. Liu, R.R.; Yu, Z.; He, Q.H.; Wang, X.; Xu, Y. Selecting mimotope of ochratoxin A from phage random peptide library and its application. Chin. J. Public Health 2005, 21, 844-946.

60. He, Q.H.; Xu, Y.; Zhang, C.Z.; Li, Y.P.; Huang, Z.B. Phage-borne peptidomimetics as immunochemical reagent in dot-immunoassay for mycotoxin zearalenone. Food Control 2014, 39, 56-61. [CrossRef]

61. Liu, X.; Xu, Y.; He, Q.H.; He, Z.Y.; Xiong, Z.P. Application of mimotope peptides of fumonisin B B $_{1}$ in peptide ELISA. J. Agric. Food Chem. 2013, 61, 4765-4770. [CrossRef] [PubMed]

62. Xu, Y.; Chen, B.; He, Q.H.; Qiu, Y.L.; Liu, X.; He, Z.Y.; Xiong, Z.P. New approach for development of sensitive and environmentally friendly immunoassay for mycotoxin fumonisin $\mathrm{B}_{1}$ based on using peptide-MBP fusion protein as substitute for coating antigen. Anal. Chem. 2014, 86, 8433-8440. [CrossRef] [PubMed]

63. Riikka, P.; Elena, B.P.; Rodrigo, B.; Ursula, S.; Martin, G.A.; María, C.M.B. Microarray-based immunoassay with synthetic mimotopes for the detection of fumonisin $\mathrm{B}_{1}$. Anal. Chem. 2017, 89, 6216-6223.

64. Yu, M.; Than, K.; Colegate, S.; Shiell, B.; Wojtek, P.M.; Stephen, P.; Wang, L.F. Peptide mimotopes of phomopsins: Identification, characterization and application in an immunoassay. Mol. Divers. 2005, 9, 233-240. [CrossRef] [PubMed]

65. Nitsara, K.; Ratthaphol, C.; Morton, M.; Michalina, O.S.; Irene, R.G.; Christopher, T.E. Development of a M13 bacteriophage-based SPR detection using Salmonella as a case study. Sens. Actuators B-Chem. 2014, 190, 214-220.

66. Yang, S.L.; Shang, Y.L.; Yin, S.H.; Wang, D.; Cai, J.P.; Gong, Z.L.; Serge, M.; Liu, X.T. A phage-displayed single domain antibody fused to alkaline phosphatase for detection of porcine circovirus type 2. J. Virol. Methods 2015, 213, 84-92. [CrossRef] [PubMed]

67. Kuang, Z.F.; Sang, N.K.; Wendy, J.C.; Barry, L.F.; Rajesh, R.N. Biomimetic chemosensor: Designing peptide recognition elements for surface functionalization of carbon nanotube field effect transistors. ACS Nano 2010, 4, 452-458. [CrossRef]

68. Cristiano, C.; Jan, W.V.; Richard, M.T.; Pier, L.L. Investigation of de novo yotally random biosequences, part I: A general method for in vitro selection of folded domains from a random polypeptide library displayed on phage. Chem. Biodivers. 2006, 3, 827-839.

69. Guo, J.; Jeffrey, M.C.; Mohamed, N.A.M.; Benesi, A.J.; Tien, M.; Kao, T.H.; Watts, H.D.; Kubicki, J.D. Identification and characterization of a cellulose binding heptapeptide revealed by phage display. Biomacromolecules 2013, 14, 1795-1805. [CrossRef] [PubMed]

70. Liu, F.F.; Wang, T.; Dong, X.Y.; Sun, Y. Rational design of affinity peptide ligand by flexible docking simulation. J. Chromatogr. A 2007, 1146, 41-50. [CrossRef]

71. Lai, W.H.; Daniel, Y.C.F.; Xu, Y.; Liu, R.R.; Xiong, Y.H. Development of a colloidal gold strip for rapid detection of ochratoxin A with mimotope peptide. Food Control 2009, 20, 791-795. [CrossRef] 
72. Xue, S.; Li, H.P.; Zhang, J.B.; Liu, J.L.; Hu, Z.Q.; Gong, A.D.; Huang, T.; Liao, Y.C. Chicken single-chain antibody fused to alkaline phosphatase detects Aspergillus pathogens and their presence in natural samples by direct sandwich enzyme-linked immunosorbent assay. Anal. Chem. 2013, 85, 10992-10999. [CrossRef] [PubMed]

73. Viti, F.; Nilsson, F.; Demartis, S.; Huber, A.; Neri, D. Design and use of phage display libraries for the selection of antibodies and enzymes. Methods Enzymol. 2000, 326, 480-505. [PubMed]

74. Yang, L.; Ding, H.; Gu, Z.; Zhao, J.; Chen, H.; Tian, F.; Chen, Y.Q.; Zhang, H.; Chen, W. Selection of single chain fragment variables with direct coating of aflatoxin $\mathrm{B}_{1}$ to enzyme-linked immunosorbent assay plates. J. Agric. Food Chem. 2009, 57, 8927-8932. [CrossRef]

75. Xu, Y.; Xiong, L.; Li, Y.; Xiong, Y.; Tu, Z.; Fu, J.; Chen, B. Anti-idiotypic nanobody as citrinin mimotope from a naive alpaca heavy chain single domain antibody library. Anal. Bioanal. Chem. 2015, 407, 5333-5341. [CrossRef] [PubMed]

76. Wang, X.; He, Q.; Xu, Y.; Liu, X.; Shu, M.; Tu, Z.; Li, Y.; Wang, W.; Cao, D. Anti-idiotypic VHH phage display-mediated immuno-PCR for ultrasensitive determination of mycotoxin zearalenone in cereals. Talanta 2016, 147, 410-415. [CrossRef]

77. Tu, Z.; Xu, Y.; He, Q.H.; Fu, J.H.; Liu, X.; Tao, Y. Isolation and characterisation of deoxynivalenol affinity binders from a phage display library based on single-domain camelid heavy chain antibodies (VHHs). Food Agric. Immunol. 2012, 23, 123-131. [CrossRef]

78. Wang, Y.; Li, P.; Majkova, Z.; Bever, C.R.; Kim, H.J.; Zhang, Q.; Dechant, J.E.; Gee, S.J.; Hammock, B.D. Isolation of alpaca anti-idiotypic heavy-chain single-domain antibody for the aflatoxin immunoassay. Anal. Chem. 2013, 85, 8298-8303. [CrossRef] [PubMed]

79. Bird, R.E.; Hardman, K.D.; Jacobson, J.W.; Johnson, S.; Kaufman, B.M.; Lee, S.M.; Lee, T.; Pope, S.H.; Riordan, G.S.; Whitlow, M. Single-chain antigen-binding proteins. Science 1988, 242, 423-426. [CrossRef] [PubMed]

80. Huston, J.S.; Levinson, D.; Mudgett-Hunter, M.; Tai, M.S.; Novotný, J.; Margolies, M.N.; Ridge, R.J.; Bruccoleri, R.E.; Haber, E.; Crea, R. Protein engineering of antibody binding sites: Recovery of specific activity in an anti-digoxin single-chain Fv analogue produced in Escherichia coli. Proc. Natl. Acad. Sci. USA 1988, 85, 5879-5883. [CrossRef]

81. Bemani, P.; Mohammadi, M.; Hakakian, A. ScFv Improvement approaches. Protein Pept. Lett. 2018, 25, 222-229. [CrossRef] [PubMed]

82. Zou, L.; Xu, Y.; Li, Y.; He, Q.; Chen, B.; Wang, D. Development of a single-chain variable fragment antibody-based enzyme-linked immunosorbent assay for determination of fumonisin $B_{1}$ in corn samples. J. Sci. Food Agric. 2014, 94, 1865-1871. [CrossRef] [PubMed]

83. Yuan, Q.; Clarke, J.R.; Zhou, H.R.; Linz, J.E.; Pestka, J.J.; Hart, L.P. Molecular cloning, expression, and characterization of a functional single-chain Fv antibody to the mycotoxin zearalenone. Appl. Environ. Microbiol. 1997, 63, 263-269. [CrossRef] [PubMed]

84. Wang, S.H.; Du, X.Y.; Huang, Y.M.; Lin, D.S.; Hart, P.L.; Wang, Z.H. Detection of deoxynivalenol based on a single-chain fragment variable of the antideoxynivalenol antibody. FEMS Microbiol. Lett. 2007, 272, 214-219. [CrossRef] [PubMed]

85. Wang, R.; Gu, X.; Zhuang, Z.; Zhong, Y.; Yang, H.; Wang, S. Screening and Molecular Evolution of a Single Chain Variable Fragment Antibody (scFv) against Citreoviridin Toxin. J. Agric. Food Chem. 2016, 64, 7640-7648. [CrossRef]

86. Rangnoi, K.; Jaruseranee, N.; O’Kennedy, R.; Pansri, P.; Yamabhai, M. One-step detection of aflatoxin-B(1) using scFv-alkaline phosphatase-fusion selected from human phage display antibody library. Mol. Biotechnol. 2011, 49, 240-249. [CrossRef] [PubMed]

87. Moghaddam, A.; Løbersli, I.; Gebhardt, K.; Braunagel, M.; Marvik, O.J. Selection and characterisation of recombinant singlechain antibodies to the hapten aflatoxin- $\mathrm{B}_{1}$ from naive recombinant antibody libraries. J. Immunol. Methods 2001, 254, 169-181. [CrossRef]

88. Li, X.; Li, P.W.; Lei, J.W.; Zhang, Q.; Zhang, W.; Li, C.M. A simple strategy to obtain ultra-sensitive single-chain fragment variable antibodies for aflatoxin detection. RSC Adv. 2013, 3, 22367. [CrossRef]

89. Rangnoi, K.; Choowongkomon, K.; O'Kennedy, R.; Rüker, F.; Yamabhai, M. Enhancement and analysis of human antiaflatoxin B 1 $\left(\mathrm{AFB}_{1}\right) \mathrm{scFv}$ antibody-ligand interaction using chain shuffling. J. Agric. Food Chem. 2018, 66, 5713-5722. [CrossRef]

90. Zhang, C.; Zhang, Q.; Tang, X.; Zhang, W.; Li, P. Development of an Anti-Idiotypic VHH Antibody and Toxin-Free Enzyme Immunoassay for Ochratoxin A in Cereals. Toxins 2019, 11, 280. [CrossRef]

91. Liu, X.; Xu, Y.; Xiong, Y.H.; Tu, Z.; Li, Y.P.; He, Z.Y.; Qiu, Y.L.; Fu, J.H.; Gee, S.J.; Hammock, B.D. VHH phage-based competitive real-time immuno-polymerase chain reaction for ultrasensitive detection of ochratoxin A in cereal. Anal. Chem. 2014, 86, 7471-7477. [CrossRef] [PubMed]

92. Liu, X.; Xu, Y.; Wan, D.B.; Xiong, Y.H.; He, Z.Y.; Wang, X.X.; Gee, S.J.; Ryu, D.; Hammock, B.D. Development of a nanobodyalkaline phosphatase fusion protein and its application in a highly sensitive direct competitive fluorescence enzyme immunoassay for detection of ochratoxin A in cereal. Anal. Chem. 2015, 87, 1387-1394. [CrossRef] [PubMed]

93. Doyle, P.J.; Arbabi-Ghahroudi, M.; Gaudette, N.; Furzer, G.; Savard, M.E.; Gleddie, S.; McLean, M.D.; Mackenzie, C.R.; Hall, J.C. Cloning, expression, and characterization of a single-domain antibody fragment with affinity for 15-acetyl-deoxynivalenol. Mol. Immunol. 2008, 45, 3703-3713. [CrossRef] [PubMed]

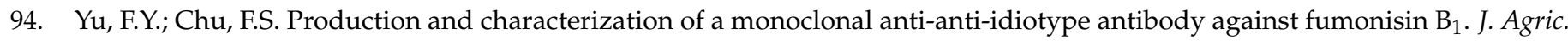
Food Chem. 1999, 47, 4815-4820. [CrossRef] [PubMed]

95. Guan, D.; Li, P.; Cui, Y.; Zhang, Q.; Zhang, W. A competitive immunoassay with a surrogate calibrator curve for aflatoxin $\mathrm{M}_{1}$ in milk. Anal. Chim. Acta 2011, 703, 64-69. [CrossRef] [PubMed] 
96. Hamers-Casterman, C.; Atarhouch, T.; Muyldermans, S.; Robinson, G.; Hamers, C.; Songa, E.B.; Bendahman, N.; Hamers, R. Naturally occurring antibodies devoid of light chains. Nature 1993, 363, 446-448. [CrossRef] [PubMed]

97. Muyldermans, S.; Atarhouch, T.; Saldanha, J.; Barbosa, J.A.; Hamers, R. Sequence and structure of VH domain from naturally occurring camel heavy chain immunoglobulins lacking light chains. Protein Eng. 1994, 7, 1129-1135. [CrossRef] [PubMed]

98. Muyldermans, S.; Baral, T.N.; Retamozzo, V.C.; De Baetselier, P.; De Genst, E.; Kinne, J.; Leonhardt, H.; Magez, S.; Nguyen, V.K.; Revets, H.; et al. Camelid immunoglobulins and nanobody technology. Vet. Immunol. Immunopathol. 2009, 128, 178-183. [CrossRef] [PubMed]

99. Zarebski, L.M.; Urrutia, M.; Goldbaum, F.A. Llama single domain antibodies as a tool for molecular mimicry. J. Mol. Biol. 2005, 349, 814-824. [CrossRef]

100. Tanha, J.; Dubuc, G.; Hirama, T.; Narang, S.A.; MacKenzie, C.R. Selection by phage display of llama conventional V(H) fragments with heavy chain antibody $\mathrm{V}(\mathrm{H}) \mathrm{H}$ properties. J. Immunol. Methods 2002, 263, 97-109. [CrossRef]

101. Guo, Y.C.; Zhou, Y.F.; Zhang, X.E.; Zhang, Z.P.; Qiao, Y.M.; Bi, L.J.; Wen, J.K.; Liang, M.F.; Zhang, J.B. Phage display mediated immuno-PCR. Nucleic Acids Res. 2006, 34, e62. [CrossRef] [PubMed]

102. Kim, H.J.; Mark, M.C.; Shirley, J.G.; Gualberto, G.G.; Bruce, D.H. Noncompetitive phage anti-immunocomplex real-time polymerase chain reaction for sensitive detection of small molecules. Anal. Chem. 2011, 83, 246-253. [CrossRef] [PubMed]

103. Dong, J.H.; Hasan, S.; Yuuichiro, F.; Hiroshi, U. Detection of small molecule diagnostic markers with phage-based open-sandwich immuno-PCR. J. Immunol. Methods 2012, 377, 1-7. [CrossRef] [PubMed]

104. Notomi, T.; Okayama, H.; Masubuchi, H.; Yonekawa, T.; Watanabe, K.; Amino, N.; Hase, T. Loop-mediated isothermal amplification of DNA. Nucleic Acids Res. 2000, 28, e63. [CrossRef] [PubMed]

105. Sagcan, H.; Kara, N.T. Detection of Potato ring rot Pathogen Clavibacter michiganensis subsp. s epedonicus by Loop-mediated isothermal amplification (LAMP) assay. Sci. Rep. 2019, 9, 20393. [CrossRef] [PubMed]

106. Rivero, R.; Bisi, M.; Velázquez, E.B.; Esteva, M.I.; Scollo, K.; González, N.L.; Altcheh, J.; Ruiz, A.M. Rapid detection of Trypanosoma cruzi by colorimetric loop-mediated isothermal amplification (LAMP): A potential novel tool for the detection of congenital Chagas infection. Diagn. Microbiol. Infect. Dis. 2017, 89, 26-28. [CrossRef] [PubMed]

107. Lei, J.; Han, X.; Tang, X.; Wang, H.; Zhang, Q. Development of Anti-Idiotypic Nanobody-Phage Based Immuno-Loop-Mediated Isothermal Amplification Assay for Aflatoxins in Peanuts. Toxins 2020, 12, 565. [CrossRef] [PubMed]

108. Vinay, V.; Michael, S.; Roman, L.; Wolfgang, B.; Rudolf, K. Simultaneous determination of 186 fungal and bacterial metabolites in indoor matrices by liquid chromatography/tandem mass spectrometry. Anal. Bioanal. Chem. 2009, 395, 1355-1372.

109. Pamel, E.V.; Annemieke, V.; Geertrui, V.; Johan, D.B.; Els, D. Ultrahigh-performance liquid chromatographic-tandem mass spectrometric multimycotoxin method for quantitating 26 mycotoxins in maize silage. J. Agric. Food Chem. 2011, 59, 9747-9755. [CrossRef] [PubMed]

110. Debjani, S.; Debopam, A.; Dipika, R.; Dilip, S.; Tarun, K.D. Simultaneous enzyme immunoassay for the screening of aflatoxin $B_{1}$ and ochratoxin A in chili samples. Anal. Chim. Acta 2007, 584, 343-349.

111. Wu, S.J.; Duan, N.; Ma, X.Y.; Xia, Y.; Wang, H.X.; Wang, Z.P.; Zhang, Q. Multiplexed fluorescence resonance energy transfer aptasensor between upconversion nanoparticles and graphene oxide for the simultaneous determination of mycotoxins. Anal. Chem. 2012, 84, 6263-6270. [CrossRef]

112. Xing, C.; Dong, X.; Xu, T.; Yuan, J.; Yan, W.; Sui, X.; Zhao, X. Analysis of multiple mycotoxins-contaminated wheat by a smart analysis platform. Anal. Biochem. 2020, 610, 113928. [CrossRef] [PubMed]

113. Xu, L.; Zhang, Z.; Zhang, Q.; Zhang, W.; Yu, L.; Wang, D.; Li, H.; Li, P. An on-site simultaneous semi-quantification of aflatoxin $B_{1}$, zearalenone, and T-2 toxin in maize- and cereal-based feed via multicolor immunochromatographic assay. Toxins $2018,10,87$. [CrossRef]

114. Chen, Y.; Chen, Q.; Han, M.; Zhou, J.; Gong, L.; Niu, Y.; Zhang, Y.; He, L.; Zhang, L. Development and optimization of a multiplex lateral flow immunoassay for the simultaneous determination of three mycotoxins in corn, rice and peanut. Food Chem. 2016, 213, 478-484. [CrossRef] [PubMed]

115. Li, R.; Meng, C.; Wen, Y.; Fu, W.; He, P. Fluorometric lateral flow immunoassay for simultaneous determination of three mycotoxins (aflatoxin $\mathrm{B}_{1}$, zearalenone and deoxynivalenol) using quantum dot microbeads. Mikrochim. Acta 2019, $186,748$. [CrossRef] [PubMed]

116. Zhang, X.; Yu, X.; Wen, K.; Li, C.; Mujtaba Mari, G.; Jiang, H.; Shi, W.; Shen, J.; Wang, Z. Multiplex lateral flow immunoassays based on amorphous carbon nanoparticles for detecting three fusarium mycotoxins in maize. J. Agric. Food Chem. 2017, 65, 8063-8071. [CrossRef] [PubMed]

117. Lattanzio, V.M.T.; Guarducci, N.; Powers, S.; Ciasca, B.; Pascale, M.; von Holst, C. Validation of a lateral flow immunoassay for the rapid determination of aflatoxins in maize by solvent free extraction. Anal. Methods 2017, 10, 123-130. [CrossRef]

118. Butler, S.A.; Khanlian, S.A.; Cole, L.A. Detection of early pregnancy forms of human chorionic gonadotropin by home pregnancy test devices. Clin. Chem. 2001, 47, 2131-2136. [CrossRef] [PubMed]

119. Hwang, J.; Lee, S.; Choo, J. Application of a SERS-based lateral flow immunoassay strip for the rapid and sensitive detection of staphylococcal enterotoxin B. Nanoscale 2016, 8, 11418-11425. [CrossRef] [PubMed]

120. Anfossi, L.; Di Nardo, F.; Cavalera, S.; Giovannoli, C.; Baggiani, C. Multiplex lateral flow immunoassay: An overview of strategies towards high-throughput point-of-need testing. Biosensors 2018, 9, 2. [CrossRef] 
121. Jawaid, W.; Campbell, K.; Melville, K.; Holmes, S.J.; Rice, J.; Elliott, C.T. Development and Validation of a Novel Lateral Flow Immunoassay (LFIA) for the Rapid Screening of Paralytic Shellfish Toxins (PSTs) from Shellfish Extracts. Anal. Chem. 2015, 87, 5324-5332. [CrossRef] [PubMed]

122. Wang, C.; Xiao, R.; Wang, S.; Yang, X.; Bai, Z.; Li, X.; Rong, Z.; Shen, B.; Wang, S. Magnetic quantum dot based lateral flow assay biosensor for multiplex and sensitive detection of protein toxins in food samples. Biosens. Bioelectron. 2019, 146, 111754. [CrossRef]

123. Climent, E.; Biyikal, M.; Gröninger, D.; Weller, M.G.; Martínez-Máñez, R.; Rurack, K. Multiplexed detection of analytes on single test strips with antibody-gated indicator-releasing mesoporous nanoparticles. Angew. Chem. Int. Ed. 2020, 59, 23862-23869. [CrossRef] [PubMed]

124. Tang, X.; Li, P.; Zhang, Q.; Zhang, Z.; Zhang, W.; Jiang, J. Time-Resolved Fluorescence Immunochromatographic Assay Developed Using Two Idiotypic Nanobodies for Rapid, Quantitative, and Simultaneous Detection of Aflatoxin and Zearalenone in Maize and Its Products. Anal. Chem. 2017, 89, 11520-11528. [CrossRef] [PubMed]

125. Ren, X.; Yue, X.; Mwakinyali, S.E.; Zhang, W.; Zhang, Q.; Li, P. Small Molecular Contaminant and Microorganism Can Be Simultaneously Detected Based on Nanobody-Phage: Using Carcinogen Aflatoxin and Its Main Fungal Aspergillus Section Flavi spp. in Stored Maize for Demonstration. Front. Microbiol. 2020, 10, 3023. [CrossRef] [PubMed]

126. Shkembi, X.; Svobodova, M.; Skouridou, V.; Bashammakh, A.S.; Alyoubi, A.O.; O'Sullivan, C.K. Aptasensors for mycotoxin detection: A review. Anal. Biochem. 2021, in press. [CrossRef] [PubMed]

127. Yeh, C.Y.; Hsiao, J.K.; Wang, Y.P.; Lan, C.H.; Wu, H.C. Peptide-conjugated nanoparticles for targeted imaging and therapy of prostate cancer. Biomaterials 2016, 99, 1-15. [CrossRef] [PubMed] 